\title{
Belt and Road Initiative: A Step toward Shared Globalization
}

\author{
Imran Ali Sandano ${ }^{1 *}$, Syed Faisal Hyder Shah², Irfan Ahmed Shaikh ${ }^{3}$ \\ ${ }^{1}$ Department of International Relations, Faculty of Social Sciences, Allama I.I.Kazi Campus, \\ University of Sindh, Jamshoro 76080, Pakistan. \\ ${ }^{2}$ Department of Social Work, Faculty of Social Sciences, Allama I.I.Kazi Campus, University of Sindh, \\ Jamshoro 76080, Pakistan. \\ ${ }^{3}$ Department of History, Faculty of Social Sciences, Allama I.I.Kazi Campus, University of Sindh, \\ Jamshoro 76080, Pakistan.
}

Received: 30 June 2019; Revised: 5 September 2019; Accepted: 12 September 2019

\begin{abstract}
Globalization is facing a major test of sustainability with growing populism and trade protectionism. West, which always endorsed for globalization has left their hands back. 'America First' and 'Brexit' has changed and challenged the original concept of globalization. China which always remained isolated from globalizations, has started to talk about globalization with its Chinese characteristics called 'Shared Globalization'. This study investigates that what kind of characteristics China has applied to get momentum for shared globalization. It is a descriptive study which has taken "One Belt, One Road" (BRI) as case study with the theoretical observation of shared development, shared future, and peaceful coexistence. The study has found that the new trends of shared globalization are emerging in Asia. It has created new opportunities for joint economic cooperation and deeper regional ntegration. The BRI policy framework is providing new drivers to the sustainable economic growth to the BRI counties and would work as a common cause for the world to restore the correct balance of globalization by making it more universally beneficial and inclusive. This study claims that shared globalization is pivotal to Eurasia with the shared attitude of new opportunities that could untangle the regions towards deeper socio-economic integration of shared development toward the community of common destiny.
\end{abstract}

Keywords: One Belt One Road; Shared Globalization; Shared Development; Share Future

How to Cite: Sandano, I. A., Shah, S. F. H., \& Shaikh, I. A. (2019). Belt and Road Initiative: A Step toward Shared Globalization. Otoritas : Jurnal Ilmu Pemerintahan, 9(2), 139-151.

Permalink/DOI: https://doi.org/10.26618/ojip.v9i2.2140

${ }^{*}$ Corresponding Author.

E-Mail : iimran110@usindh.edu.pk

Copyright (C) 2019, Otoritas : Jurnal Ilmu Pemerintahan, ISSN: 2088-3706 (Print), ISSN: 2502-9320 (Online) 
Available Online at https://journal.unismuh.ac.id/index.php/otoritas

Otoritas : Jurnal Ilmu Pemerintahan, 9 (2), October 2019, 140

\section{INTRODUCTION}

Brexit and "America First" are the evidences that the globalization is dwindling toward the nationalism, protectionism, and isolationism in the West (Ahearn, 2006; Brands, 2017; Crouch, 2017). Some even believe that the era of globalization is rolling toward its ending stage. (Ikenberry, 2018) Many Western countries have realized that "the globalization which gained traction after the financial crisis is no longer their promulgated globalization". Thus, the "Western powers are shifting back towards putting in place barriers to protect their own private interests," with the result that "international trade is in its worst period in 30 years" (Rong, 2016). In the meanwhile, Chinese worldview and globalized perspective of the free flow of commerce remained unimpeded, but the status quo are no longer suited to the U.S. and EU trade and political preferences. Therefore, their commitment to the free flow of trade has changed toward the self-serving impulses in shape of trade protectionism (Brands, 2017; Crouch, 2017).

Among the rising voice for greater trade protectionism and nationalism in the West in lieu of global economic disquiet, China retorts to neoliberalism's crises by taking effective measures to redefine and reorient the globalized practices in the world in shape of providing a new alternative model of shared development for mutual benefits (Brandt \& Rawski, 2008). China's opening-up policy and key initiative of "One Belt, One Road" (BRI) along with other key international projects like BRICS, New Development Bank, Asian Infrastructure Investment Bank, expansion of Shanghai Cooperation Organization and National Silk Road Fund, has opens up new opportunities for joint economic cooperation and deeper regional integration which may lead to a new shared development model of globalization (Huang, 2016).
China has shown its commitment to shoulder more responsibility and play its due role in global economic stability by reorienting the balance in economic globalization that will make it more universally beneficial and inclusive (Assadi, 2017). The shared developing model that advocate the "win-win" bilateral trade deal for mutual benefits. However, the Chinese perspective of globalization is different from US neoliberal globalization. China believes in multilateral credit and strategic international economic collaboration to address economic development, foreign investment, employment, and infrastructure development. This realization comes from its own comprehensive development experience which has produced quick results of utmost self-reliance through engagement of comparatively low-income people as suppliers of goods, services and work. Socially, it indicates a model in which the managements of the both markets and the state accompanies were developed equally. In the economic terms, The BRI is not only planned to obtain economic profits as the neoliberals did but with "win-win" outcomes for participating countries as well. While politically, collaboration is open and comprehensive for all, without any political interference in the participating countries national affairs (Liu \& Dunford, 2016). In these ways, China believes to build a new comprehensive international platform where shared globalization will benefit more people and regions.

This article aims to provide theoretical understanding to the concept of shared globalization through shared development model and also highlight the China's motivations for BRI which has emerged as an internal and external policy framework for an inclusive and openly "win-win" cooperation model based on shared development.

The "Road Belt Initiative" founded its roots in the ancient Chinese philosophy of "Silk Road Spirit" that advocate the 
promotion of peace, cooperation, openness, inclusiveness, mutual learning and mutual benefit among all the civilization (Xinhua, 2015). The BRI are often considered as a game-changer that will connect the land hindered economies of Asia, Europe, and Africa. The "Belt" is consist of vibrant networks of roads and railways that will connect the Western part of China to the Western Europe via Central Asian states, Iran, Turkey, Russia, the Caucasus, and the Balkans countries. Besides, linking Eurasia by land the "21st Century Maritime Silk Road" is proposed to connect the China with South Asia, Southeast Asia, Middle East, Africa and Europe through a strip of Sea ports via the South China Sea, the Indian Ocean, and the Mediterranean Sea (Nadège Rolland, 2017). The Chinese government is committed to fully developed and operationalized the six economic corridors, namely, ChinaMongolia-Russia Economic Corridor (CMREC), China-Pakistan Economic Corridor (CPEC), Bangladesh-China-IndiaMyanmar Economic Corridor (BCIMEC), China-Indochina Peninsula Economic Corridor (CICPEC), China-Central and West Asia Economic Corridor (CCWAEC), the New Eurasian Land Bridge (NELB) along with parallel networks of oil and gas pipelines, telecommunication links, and high speed fiber optic cables for better transportation and convectively among the transregional nations (Luft, 2016). The Chinese authorities believe that transportation infrastructure is "the first step in creating an economic corridor that will integrate the landlocked economies of the Eurasian hinterland and tie them more tightly to China" (Nadège Rolland, 2017). iThe BRI related projects involve $70 \%$ of the global population, $75 \%$ of its known energy reserves and territory, $25 \%$ of global trade and $55 \%$ of global GDP (Lehmacher, 2016).

The general perspective of the globalization used to be consider as western-globalization (Shenming, 2000) or 'westernization' (Inozemtsev, 2004). It was also called global capitalism (Gilpin, 2018) which used to be flourished with the help of neo-liberal trade policies and free trade agreements. The main purpose of western globalization was to produce unprecedented levels of wealth accumulation for corporations and those who run them. No doubt that many countires developed themselves under the shadow of globalization but it also brought big gap between North and South (Johnson \& Wilson, 2006). This study claims that Chinese characteristics of 'Shared Globlization' are very new and understandable. It has no hidden agenda and common to all without any discrimination. Mainwhile the originators of globalization are moving towards individualization (Jamieson \& Simpson, 2013) and nationalization (Zahid, 2015). The protectionist sentiments are taking over in major economies of specially from West (Ghemawat, 2017). Populist or right-wing parties are also flourishing across the developed world (Inglehart \& Norris, 2017). BRI is one of the key turning points in the world political system which is filling the research gap of this study. Shared development, shared future and peaceful coexistence are the key approaches of BRI which are analyzing the shared globalization with flourishing mode.

\section{RESEARCH METHODS}

The paper has been written on the basis of current primary and secondary sources that address the changing nature of globalization and shifting towards new shape (Share Globalization) under the shadow of BRI.

The study carried out a descriptive research by employing qualitative and analytical framework based on available primary and secondary sources. The claimed phenomenon of shared globalization would be described by applying a qualitative and analytical approach with shared development, shared future, and 
peaceful coexistence. BRI has been taken as the case study to check the rationality and reliability of shared globalization data obtained from books, articles from academic journals, newspapers.

\section{RESULTS AND DISCUSSION}

Globalization is always discussed in the political and academic arena, but there is no widespread consensus on its extent and definition (Amin \& Thrift, 1995). In fact, globalization is a transformation process of prevalence from nation -states to an amalgamation between the countries. It represents both economic and social linkages that extend from economic deregulation to the technological innovation. These drivers have succeeded to demote the trade barriers, mounted the trade flow between the nation-states, gave fast growth to the global financial markets and enlarged the activity of multinational companies. The rapid innovation in the field of information technology also facilitated the development of extraordinary patterns that changed the increased global sourcing. Putting limitation in the role of government involvement in both economic and social policy with growing emphasis on the free market with an ambition to make the world a "global village" (Amin \& Thrift, 1995).

Some would claim that globalization has not brought any change that actually represents a dissent of the dimensions, because some countries have achieved huge benefits and some have nothing. There is a "hyper-globalist perspective" which argues that global markets are completely unified, and national economies have mostly become inessential. But on the other hand, the "skeptical perspective of globalization" indicated that international practices have existed, but the national economies remained as a dominant factor within it (Hirst, Thompson, \& Bromley, 2015). However, gradually the focus shifted on the process of complicated globalization that is based on the multidimensional practices with historical roots including both change and continuity (R, 1999). Higgott believes that "globalization is developing and by no means an irreversible process in which a range of state actors, international institutions and non-state actors such as multinational corporations, global social governments, and non-governmental organizations play increasingly significant roles" ( $\mathrm{R}, 1999) . "$

Most of the Western debate over globalization has always been sidelined the role of developing countries, yet these countries hold the majority of the world's population. They have been severely affected by western global integration and economic liberalization through the burden of maintenance and structural modification programs. They have never been close to the homogeneous process (Hoogvelt, 2001). The implications of global integration have always remained diverse between countries. Some counties have been capable enough to establish export markets and take part in global financial trade while others counties have found it tough.

In simple words, globalization can be divided into two different ways "Capitalism" and "Corporate Capitalism". Capitalism is a process of global transformation which is playing a key driving force behind numerous changes. On the other hand, the corporate capitalism is a process that exceeds nation states, institutions, cultures, markets, and economies. It seems that the process of Western promoted globalization involved huge number of contributing forces or factors such as, technological innovations, weakening domestic economies, involving third world counites in wars, political and military lobbies. The downfall of former Soviet Union is also part of their stratgy to create west domenant global system. They have used United Nations and her agencies like as the World Bank, International Monetary Fund, and World Trade 
Organization and United States Agency for International Development to give promotion to their own ideology. They increased expectations of people, dreams for grassroots sharing of power in organizational and management democracy is to get their vasted interest and nonstop distruption to cheap labor force (Farazmand, 2007).

Globalization represents growing international economic interdependence across national borders and an exclusive increase in foreign direct investment, international trade, global movements of people, ideas, and technologies (Sheppard, 2016). It has made possible to develop technologies, liberalize international investment regimes, remove trade barriers, and soften domestic regulations. The early wave of globalization boosted the global shift of services and manufacturing to some leading economic powers but decimate the economic development in the third world countries. Although, some countries with extensive domestic and inward investment achieved remarkable growth and succeeded in reducing poverty and improving the lives of millions of people. On the other hand, globalization also increased the global poverty and inequality between the South and North. Some countries did not get any productive results and fall behind others which have reduced the fellow well-paid jobs.

The West, which was for decades remained proponent and champion of free trade and globalization has showed the tendency of skepticism about major cross border military, political, and economic alliances (Lam, 2017). Because they always maintained the one-way road for exploitation and monopolization of the third world, their cheap labors and financial markets. Thus, it has become easy for the developed West to start a campaign against immigrants, blaming them for occupying their jobs and creating problems like crime and terrorism. No one can deny that on the one side globalization is facing a major test of sustainability in the West with growing populism and trade protectionism, but on the other hand, trend of globalization is spreading in Asia. It is creating new opportunities to the regional states for deeper socioeconomic integration.

President Xi Jinping's strategic foreign policy initiative in 2013, BRI has provided an alternative vision of globalization that based on mutual cooperation and shared development toward shared future (Xi, 2014). The major geopolitical transition and dramatic changes in the Western political landscape has encouraged the China to take the BRI initiative. The balance of economic and political power is shifting from the West to the East with the 21st century seen as the Asian century.

The world is witnessing the transition of China from being a regional economic power to a significant global power. Therefore, the initiative was often termed as a Beijing's strategic effort to boost its soft image as a constructive actor in its neighborhood through shared model of economic and social success that respects the sovereignty of and the equality among nations (Gill \& Huang, 2006).i The BRI initiative is a part of "Chinese Dream" to "leverage China's growing economic power and influence (along its periphery) in order to strengthen and expand cooperative interactions, create an integrated web of mutually beneficial economic, social and political ties, and ultimately lower distrust and enhance a sense of common security" (Swaine, 2015).

The model of shared globalization is based on "win-win cooperation" that offers the world a unique state of bigger openness, integration, and interdependence with a comprehensive approach to shared development and shared future. It proposes vast new development opportunities like BRI initiative, BRICS New De- 
Available Online at https://journal.unismuh.ac.id/index.php/otoritas

Otoritas : Jurnal Ilmu Pemerintahan, 9 (2), October 2019, 144

velopment Bank, Asian Infrastructure Investment Bank, expansion of Shanghai Cooperation Organization and National Silk Road Fund (Sandano, 2017). If full operationalization, these projects will give a unique impact on the sustainability of shared globalization within Asia and outside world.

The approach toward shared globalization is more inclusive and balanced. It will be beneficial for both, China's own economic stability and balanced development of different regions as well. The shared global globalization model advocate the mutual sustainable development based on the idea of "win-win" cooperation for equal benefits and advantages and also guarantee state ownership and sovereign identity.

The idea of shared globalization seems similar to the "Peace of Westphalia" that advocate for the system of equal and peaceful coexistence of sovereign states by the safeguarding the interest of the "Other" (Straumann, 2008). The shared globalization is based on two main components (shared development and shared future) and both are interconnected with each other (See Figure 1).

\section{Shared Development}

Shared development is the core component of shared globalization. President Xi Jinping coins the concept of shared development as a last of the five development ideas. It is ranked fifth not because it is least important, but because it needs the prior success of the innovative development, coordinated development, green development, and open development concepts (Kuhn, 2016). At the national level, the shared development concept fits at the fifth position but at the global scale, it is important approach with multidimensional ranges. Shared development is a process of endorsing justice and interest in developing the neighboring countries. It offers assistance to their abilities and sincerely helps them to achieve faster-shared growth. It is a channel of active connectivity between countries and the regions of the world to establish financing platform and regional infrastructure investment through land and sea. It would create a trusted environment which will not only benefits China but to all coordinating participants (Yi, 2015).

The coordinating member participants would create regional integration

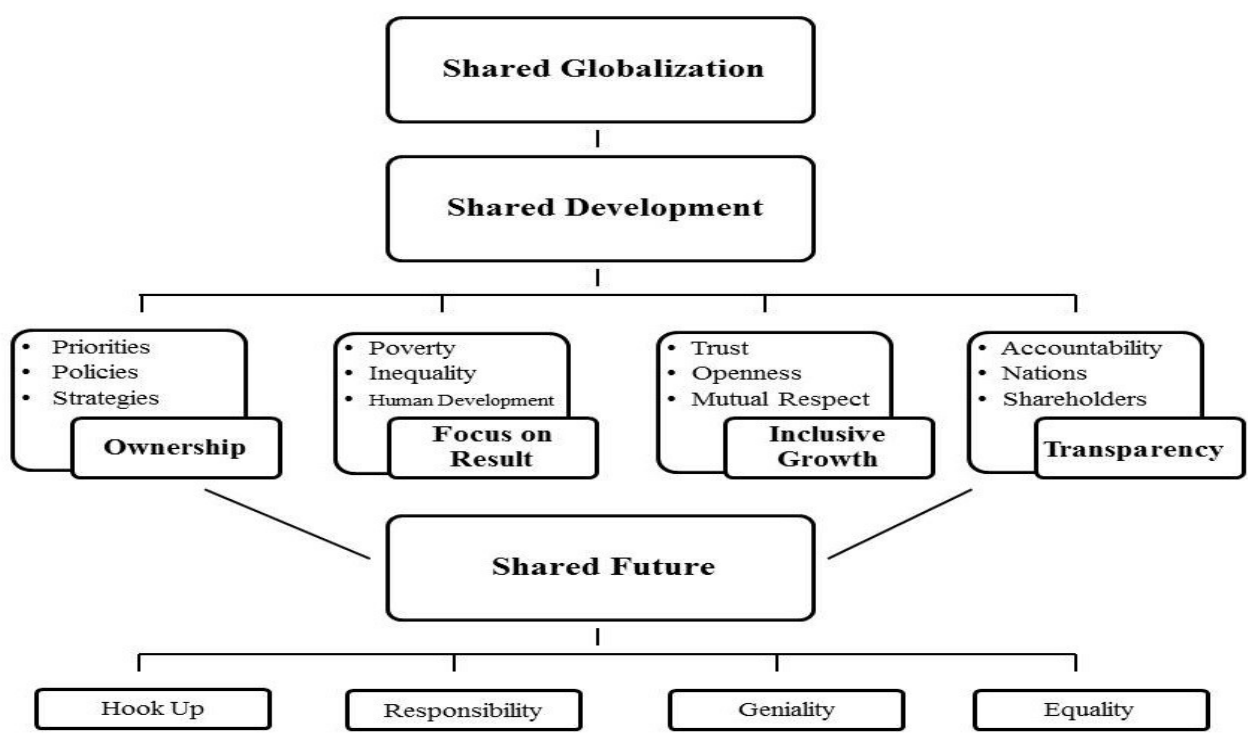

Figure 1. Proposed Model of Shared Globalization Source: Processed by the authors (2019) 
which is an open phase of shared development. This thriving attitude would boost peace and prosperity within and outside the region. Shared development has long-term global implications for western neglected developing countries. It depicts much more flexible shared economic growth arrangements globally. It demonstrates a state of shared world development in which the real goal of globalization would be achieved. Although it is under explorative and experiment process, the ultimate result is the shared growth trends. For further understanding, shared development are characterized by four keys principles; a) ownership, b) result focused, c) inclusive growth and, d) transparency.

First, the partnership of shared development can only be accomplished, when the ownership is given to the participating countries. The ownership of the host countries over their development strategies and policies is critical for successful partnerships. This means that shared development ought to align with participant countries through their own policies, priorities, and systems. Second, focus on result ensures that shared development should have prominent impacts on reducing inequality, eradicating poverty, facilitate human development, improve capabilities and capacities of the participating nations. These two principles are closely entangled with the intention to increase focus on development results. Therefore, if all the participant countries are agreed on such principles that would give more support to the shared development model and will boost the ownership of the member states through their own policies and priorities.

Third, inclusive growth is another core principle of shared development model. It explains a stronger engagement and recognition of state and non-state development actors, including the civil society. The active involvement of these agents in any national system requires more time and effort for shared development. Therefore, inclusive growth can only be achieved through requires trust, openness, and mutual respect for effective partnerships in support of shared development goals. Fourth, transparency is more than an essential tool and a foundation for accountability. The transparent and equal information on resources, their objectives, terms, and conditions, gives the base for mutual evaluations of shared development progress. Mutual transparent accountability would provide expected benefits to all participating nations, citizens, organizations, and shareholders. These two principles are closely entwined with the country-led transparent and inclusive framework that monitor shared development and endorse mutual accountability.

These four principles are the essential part of the shared development model and will boost the independent ownership of shared development, its policies, and practices. These principles will play a significant role in the support efforts to achieve sustainable and concrete results. The system of shared supervision for proper monitoring, evaluating, communication, and results; along with scaling up the support of host country to strengthen national capacities and various investment resources will ensure the good results from shared development model. The successfully shared development would ultimately tailor the horizontal collaboration among the various countries and would lead toward shared globalization.

\section{Shared Future}

On November 2012, the 18th National Congress of the Communist Party of China proposed the concept of "a community of shared future for all humankind" ("Shared future for all a win-win concept," 2017). Thereafter, President Xi Jinping has repeatedly been highlighted the concept of shared future on many in- 
ternational and national forums. The concept, mainly designed to help and solve the key problems faced by the humankind. It reflects the Chinese perception of global responsibility which bounds to leave its mark in international politics. China believes that this concept is a fundamental part of its five thousand years old civilization. In fact, it is an innovative development of the traditional Chinese principles in the new era of shared globalization, where all nation states are interconnected, and joint collaboration is a likely path of promoting shared development for shared future.

China believes that 'a community of shared future for all humankind' would be a guideline for the world in the 21st century. The idea was also echoed in the United Nations Security Council and adopted in the shape of UN resolution on March 17, 2017 ("Shared future for all a win-win concept," 2017). This acknowledgment indicates the China's sincere efforts and global responsibility toward shared globalization. President Xi Jinping in his historical speech in the United Nations said that "there is only one Earth in the universe and we mankind have only one homeland. It is the only home to mankind, so to care for and cherish it is the only option for mankind" (News, 2017). He reiterated that "We should not only think about our own generation but also take responsibility for future ones. All countries should jointly shape the future of the world, write international rules, manage global affairs and ensure that development outcomes are shared by all" (News, 2017).

In the current wave of shared globalization and shared development, the shared future can be understood in four key principles such as: First, hook up the argument of shared future emphasis on ideas that binds the international community together rather abridge differences and split by prioritizing a shared future over divided endowment. Second, responsibility - focus on responsibilities that China believes would appropriate for shared globalization and shared development which ultimately creates opportunities for both national and international community.

Third, ethics of geniality - emphasis on non-interference and mutual respect that recognizes the peace and prosperity of all participating nations through shared globalization. Fourth, equality that perches' fairness and trust between all stakeholders for mutual benefits. The vision of shared future enables the international community to recognize national, regional and global responsibility. Shared globalization and shared development are the essential elements of shared future which would transform the dynamics of international community and bring it together. The BRI is an effort toward 'a community of shared future for all humankind' and indicates the spirit of Chinese diplomatic characteristics and responsible attitude for "win-win" cooperation.

\section{China's Motivations for BRI}

First, the development of China is at a crossroads. It is restructuring and upgrading its economic initiatives from factor-intensive and export-orientation to a more innovative, sustainable and balanced path. These forces are pushing it to pursue a new and active part in global markets. Some scholars argue that the BRI initiative is "a tool for promoting national economic development by boosting exports, enhancing access to natural resources, and providing support to important domestic industries" as many Chinese academician see it as an effort to relieve the overcapacity in certain Chinese capital goods and construction-oriented industrial sectors (Nadege Rolland, 2015).

Second, China's corridors on economic development and its impact on the global environment possibly explain the pathway for other developing economies of the region. Its foreign policy is based on 
peaceful cooperation and has never shown imperialistic attitude toward any nation state. Its economic growth is also based on mutual benefits. It believes that these initiatives would contribute to our own development and expanded areas where its interest meets with other sides. It wants to secure its own development and oblige the genuine concerns of other developing countries. According to standard economic and trade rules, China wants market access and safeguards the legal rights and interest of its partners. It wants shared development for enhancing the capacity of a partner to establish their independent development and to improve the lifestyle of their people, which may narrow the gap between the South and North. China insisted that it will never seek profit at the cost of others or move its fracas against others (Cho \& Jeong, 2008). These motives show that it is the right time for China to demonstrate shared globalization for equity, economic growth, poverty reduction, human development, and social and cultural respect. China is determinant that shared globalization would only work through shared development for shared future (Kuhn, 2016).

Third, the ancient Silk Roads on sea and land also provided significant development and prosperity to the Asian, European, and African countries for thousands of years. The BRI is a "Silk Road Spirit", which endorses peace and cooperation, mutual learning and mutual benefit, openness and inclusiveness, and shared cultural heritage of all participating countries. It proposes the intention of encouraging economic cooperation among countries by promoting the arranged free-flow of economic features and the productive allocation of resources. The BRI run through the continents of Asia, Europe, and Africa, linking stimulating East Asia economic milieu at one end and developed Europe at the other, and encircling many countries with enormous economic development perspective. It also shows strength to discover new models of shared globalization, which would create constructive contributions to world peace and development (Shan, 2016).

Fourth, China is trying to reshape global geopolitics through BRI and returning Eurasia to its historical and significant position of the center of human civilization. The two great civilizations of East and West were connected with each other until the rise of the Ottoman Empire that cut off the ancient Silk Road (Yiwei, 2015). That development pushed Europe to move toward the sea and lead globalization through colonization. The Eastern civilizations become conservative, and the world became Western centered. However, the rising voices of anti-globalization rhetoric are in United States and declining influence of Europe due to the Brexit. Europe would have a historic chance to return to the center of the world through the revitalization of Eurasia.

Finally, the BRI initiative is offering ownership, focus on the result, inclusive growth, and transparency. It seems a step towards shared globalization by linking all deprived regions; Central Asia, West Asia, South Asia, and Southeast Asia. It foresees systemic innovation and infrastructure development which help to improve the economic environment in participating countries and the regions.

This regional connectivity will contribute greater complementarity and help to establish and improve the shared industrial chain, supply chain, and value chain hence brings Eurasian and PanAsian regional cooperation to a shared development (Yi, 2015). This would push forward global cooperation between China and the world. It would not only help China to rise, but all the participating nations with shared growth momentum and will create more inclusive shared globalization. 
Available Online at https://journal.unismuh.ac.id/index.php/otoritas

Otoritas : Jurnal Ilmu Pemerintahan, 9 (2), October 2019, 148

\section{CONCLUSION}

Inclusive The Belt and Road Initiative offered considerable potential in several strategic, economic, political and cultural areas. Some of the strategic scholars termed this initiative as a China's grand strategy to established its political influence and reshape at least its own neighborhood through economic development to neutralize the future risk of countervailing responses (Nadège Rolland, 2017). The Xi Jinping government is esthetically persuading the BRI initiative as a symbol of China's foreign and economic policy with invincible supported form the Chinese strategic observers. Although, some scholars have doubted that BRI might not enhanced Beijing's political influence across Eurasia regions but have little doubt that it would generate the huge development and economics activities across the trans-regional states (Nadège Rolland, 2017).

The BRI initiative has already won support of over 100 countries and international organizations. Nearly, 50 cooperation agreements has already been signed between the Chinese governemnts and other participating countries $(\mathrm{Du} \&$ Zhang, 2018). The participation of over 130 countries representatives (world's major economies) including the head of states in a two-day forum "The Belt and Road Forum for International Cooperation" on 15-16 May 2017, is evident that China's discourses of peaceful cooperation for "win-win" gains are gaining international influence, and thus, the world has started accepting a Chinese discourses (Xinhua, 2017).The BRI has initiated a global communication system led by China and its discourse are gradually gaining more currency. Through BRI, the country is exercising its international communication and international discourse power to attain the "Chines Dream" of national prosperity, socialism and national (Bao, 2016).
These initiatives surrounding BRI are expected to provide a favorable external environment to promote China's image as a responsible global power. The $\mathrm{BRI}$ is a joint initiative that embraces the trend towards a multipolar world that advocate the idea of shared globalization, shared development, and shared future. It will not only promote the development of the international economy but also will provide a platform to the potential developing countries to growth shoulder by shoulder. The initiative aims to improve the connectivity of Asian, European, and African continents and their adjacent seas, set up multi-tiered and composite connectivity networks, and realize diversified, independent, and sustainable development in these countries. In short, it is intended to be based on a new logic of shared interests and common development, rather than the conventional logic of balance of power.

The BRI initiative is offering ownership, focus on the result, inclusive growth, and transparency. It seems a step towards shared globalization because it is linking all deprived regions Central Asia, West Asia, South Asia, and Southeast Asia. It foresees systemic innovation and infrastructure development which help to improve the economic environment in participating countries and the regions. This regional connectivity will contribute greater complementarity and assist in establishing and improving the shared industrial chain, supply chain, and value chain hence brings Eurasian and PanAsian regional cooperation to a shared globalization (Yi, 2015).

To conclude, the BRI initiative is based on a core idea of peace, cooperation, development, and mutual benefit. It emphases on five fundamental values, a) policy coordination, b) facilities connectivity, c) unimpeded trade, d) financial integration and, d) people-to-people bonds. It also marks three communities, a) community of shared interests, b) com- 
Available Online at https://journal.unismuh.ac.id/index.php/otoritas

Otoritas : Jurnal Ilmu Pemerintahan, 9 (2), October 2019, 149

munity of common destiny and, c) community of responsibility. These approaches acutely reflect Chinese thinking for shared globalization, shared development and shared future which spark new hope to achieve peace and development in the world.

\section{ACKNOWLEDGEMENT}

We would like to express our gratitude to our respective departments of the Faculty of Social Sciences, University of Sindh, Jamshoro. Pakistan.

\section{REFERENCES}

Ahearn, RJ. (2006). Europe: Rising Economic Nationalism? Congressional Research Service. Paper presented at the Library of Congress: Washington, DC, USA.

Amin, A., \& Thrift, N. (1995). Globalization, institutions, and regional development in Europe: Oxford university press.

Assadi, MZ. (2017, March 9). One Belt One Road is a new form of globalization: China, The Caspian Times. Retrieved from http:// www.thecaspiantimes.com/onebelt-one-road-new-formglobalization-china/

Bao, X. De. (2016). One Belt, One Road: China's reconstruction for global communication and international discourse power. International Institute for Asian Studies(Summer ).

Brands, H. (2017). US grand strategy in an age of nationalism: fortress America and its alternatives. The Washington Quarterly, 40(1), 73-94.

Brandt, L., \& Rawski, T. G. (2008). China's great economic transformation: Cambridge university press.
Cho, Y. N., \& Jeong, J. H. (2008). China's soft power: Discussions, resources, and prospects. Asian survey, 48(3), 453-472.

Crouch, C. (2017). Neoliberalism, nationalism and the decline of political traditions. The Political Quarterly, 88(2), 221-229.

Du, J., \& Zhang, Y. (2018). Does one belt one road initiative promote Chinese overseas direct investment?. China Economic Review, 47, 189205.

Farazmand, A. (2007). Globalization: A theoretical analysis with implications for governance and public administration. PUBLIC ADMINISTRATION AND PUBLIC POLICYNEW YORK-, 129, (3).

Ghemawat, P. (2017). Globalization in the age of Trump. Harvard Business Review, 95(4), 112-123.

Gill, B., \& Huang, Y. (2006). Sources and limits of Chinese 'soft power'. Survival, 48(2), 17-36.

Gilpin, R. (2018). The challenge of global capitalism: The world economy in the 21st century: Princeton University Press.

Hirst, P., Thompson, G., \& Bromley, S. (2015). Globalization in question: John Wiley \& Sons.

Hoogvelt, A. (2001). Globalization and the postcolonial world: The new political economy of development: JHU Press.

Huang, Y. (2016). Understanding China's Belt \& Road initiative: motivation, framework and assessment. China Economic Review, 40, 314-321. 
Ikenberry, G. J. (2018). The end of liberal international order?. International Affairs, 94(1), 7-23.

Inglehart, R., \& Norris, P. (2017). Trump and the populist authoritarian parties: the silent revolution in reverse. Perspectives on Politics, 15 (2), 443-454.

Inozemtsev, VL. (2004). Westernization as globalization and" globalization" as Americanization. Voprosy filosof(4), 58-69.

Jamieson, L., \& Simpson, R. (2013). Living alone: Globalization, identity and belonging: Springer.

Johnson, H., \& Wilson, G. (2006). NorthSouth/South-North partnerships: closing the 'mutuality gap'. Public Administration and Development: The International Journal of Management Research and Practice, 26 (1), 71-80.

Kuhn, Robert Lawrence. (2016, November 12). Shared development as the last concept, China Daily.

Lam, David. (2017, February 3). China and Europe: Winners in Globalization's New World Order. Atlantic Bridge.

Lehmacher, W. (2016). Why China could Lead the Next Phase of Globalization. Paper presented at the World Economic Forum.

Liu, Weidong, \& Dunford, Michael. (2016). Inclusive globalization: unpacking China's Belt and Road Initiative. Area Development and Policy, 1(3), 323-340. doi: $10.1080 / 23792949.2016 .1232598$

Luft, G. (2016). It takes a road: China's one belt one road initiative: An American response to the new silk road. Institute for the analysis of global security.

News, X. (2017, January 18). Work Together to Build a Community of Shared Future for Mankind," Speech by H.E. Xi Jinping, President of the People's Republic of China, At the United Nations Office at Geneva, Xinhua News. Retrieved from http://news.xinhuanet.com/ english/2017-01/19/ c_135994707.htm

R, H. (1999). The need for a balanced diet in the era of globalization. New Political Economy(4.1), 23-36.

Rolland, N. (2015). China's new silk road. The national bureau of Asian research, 12.

Rolland, N. (2017). China's "Belt and Road Initiative": Underwhelming or game-changer? The Washington Quarterly, 40(1), 127-142.

Rong, F. (2016). Zhongguo Ying Daitou Fandui Ni Quanqiuhua Chaoliu. Beijing Ribao.

Sandano, I. A. (2017, March 28). One Belt One Road: A Step Towards Globalization. Eurasia Review.

Shan, W. (2016). The Silk Road Spirit in a time of globalization Retrieved from https:// blog.oup.com/2016/05/silk-roadspirit-globalization/

Shared future for all a win-win concept. (2017, March 25). China Daily. Retrieved from http:// www.chinadaily.com.cn/ opinion/2017-03/25/ content_28675525.htm 
Available Online at https://journal.unismuh.ac.id/index.php/otoritas

Otoritas : Jurnal Ilmu Pemerintahan, 9 (2), October 2019, 151

Shenming, L. (2000). Globalization and the Third World. SOCIAL SCIENCES IN CHINA(3), 03.

trieved from https:// eng.yidaiyilu.gov.cn/qwyw/ qwfb/1084.htm

Sheppard, E. (2016). Limits to globalization: The disruptive geographies of capitalist development: Oxford University Press.

Straumann, B. (2008). The Peace of Westphalia (1648) as a Secular Constitution. Constellations, 15(2).

Swaine, M., D. (2015). Chinese views and commentary on the 'One Belt, One Road'initiative. China Leadership Monitor, 47(2), 3.

Xi, J. (2014). Seek Sustained Development and Fulfill the Asia-Pacific Dream. APEC China.

Xinhua. (2015, March 30). Vision and Actions on Jointly Building Silk Road Economic Belt and 21st-Century Maritime Silk Road, Xinhua. Re-

Xinhua. (2017, April 12). China Focus: World's major economies present at B\&R forum, Xinhua News. Retrieved from http:// news.xinhuanet.com/ english/2017-05/15/ c_136283034.htm

Yi, H. (2015). China's 'One Belt/One Road'Policy Is Open to All Nations. Executive Intelligence Review.

Yiwei, W. (2015). One belt one road: Opportunities for Europe-China cooperation. Europe's World, 13.

Zahid, G. (2015). Globalization, nationalization and rationalization. Procedia-Social and Behavioral Sciences, 174, 109-114. 